\title{
Philosophiques
}

\section{Livres reçus (automne 2011)}

Volume 38, numéro 2, automne 2011

URI : https://id.erudit.org/iderudit/1007475ar

DOI : https://doi.org/10.7202/1007475ar

Aller au sommaire du numéro

Éditeur(s)

Société de philosophie du Québec

ISSN

0316-2923 (imprimé)

1492-1391 (numérique)

Découvrir la revue

Citer ce document

(2011). Livres reçus (automne 2011). Philosophiques, 38(2), 635-635.

https://doi.org/10.7202/1007475ar

Ce document est protégé par la loi sur le droit d'auteur. L'utilisation des services d'Érudit (y compris la reproduction) est assujettie à sa politique d'utilisation que vous pouvez consulter en ligne.

https://apropos.erudit.org/fr/usagers/politique-dutilisation/
Cet article est diffusé et préservé par Érudit.

Érudit est un consortium interuniversitaire sans but lucratif composé de l’Université de Montréal, l'Université Laval et l'Université du Québec à Montréal. Il a pour mission la promotion et la valorisation de la recherche. https://www.erudit.org/fr/ 


\section{Livres reçus (automne 2011)}

Conche, Marcel, La liberté, St-Just-La-Pendue, Les Belles Lettres, coll. Encre Marine, $201 \mathrm{I}, 97 \mathrm{p}$.

Maffre-Castellani, Françoise, Edith Stein. Le livre aux sept sceaux, Paris, Édition Orizons (Distribution l'Harmattan), I64 p.

Marty, Anton, Deskriptive Psychologie, dir. par Mauro Antonelli et Johann Christian Marek, Wüzrburg, Königshausen und Neumann, 20 I I 2 I I p.

Panaccio, Claude, Qu'est-ce qu'un concept?, Paris, Vrin, coll. Chemins philosophiques, $20 \mathrm{II}$, I28 $\mathrm{p}$.

Tiercelin, Claudine, Le ciment des choses. Petit traité de métaphysique scientifique réaliste, Paris, Éditions Ithaque, coll. Science et métaphysique, 20I I, $400 \mathrm{p}$.

Roy, Jean-Michel, Rhin et Danube. Essai sur le schisme analytico-phénoménologique, Paris, Vrin, coll. Problèmes et controverses, 2010, 544 p.

Russell, Bertrand, Pourquoi je ne suis pas chrétien, préface de Normand Baillargeon, traduit de l'anglais par Guy Le Clech, Montréal, Lux Éditeur, 20I I, 206 p.

Outre les ouvrages qui apparaissent dans cette liste, la rédaction de Philosophiques peut obtenir, pour fin de compte rendu ou d'étude critique, la plupart des livres parus récemment.

Les personnes désireuses de faire un compte rendu ou une étude critique sont priées de s'adresser à:

Guillaume Fréchette

Philosophiques

Département de philosophie

Université du Québec à Montréal

c.p. 8888, succ. Centre-ville

Montréal, Qc

$\mathrm{H}_{3} \mathrm{C}{ }_{3} \mathrm{P} 8$

frechette.guillaume@uqam.ca 